\title{
Wpływ funkcjonowania poligonu artyleryjskiego na życie Torunia w latach 1867-1939 w świetle lokalnej prasy
}

Pawet Pilarski*

\section{Wstęp}

Toruński poligon artyleryjski ma już ponad czterysta lat. Pierwsze odnotowane strzelania (ćwiczenia) odbyły się tu na początku siedemnastego wieku, stąd też często uważany jest za najstarszy poligon artyleryjski w Europie. Przez wieki zmieniał swoje oblicze i powierzchnię. Przemaszerowało przez jego wydmowe tereny kilkaset tysięcy żołnierzy wielu armii. Ziemie poligonu doświadczyły niejednego wybuchu salw armatnich, prób nowinek artyleryjskich i czuły ciężar gąsienic kilkutonowych wozów. Z toruńskim poligonem związane są również dramatyczne wątki. Wiele osób zginęło tutaj pełniąc służbę podczas odbywanych ćwiczeń, walk prowadzonych na terenie poligonu czy też z braku odpowiedzialności przy zbieraniu niewypałów.

Toruński poligon artyleryjski doczekał się kilku publikacji, jednak nadal nie ma pełnej monografii na jego temat. W Katedrze Nauk Humanistycznych Wyższej Szkoły Oficerskiej powstało kilka prac na temat dziejów poligonu. Warto tutaj wspomnieć o rozprawie Roberta Niedba-

\footnotetext{
*Wojskoznawca, student na Uniwersytecie Mikołaja Kopernika w Toruniu, Społeczny Opiekun Zabytków, członek sekcji fortecznej TOnZ w Toruniu, przewodnik po Toruniu i Twierdzy Toruń, popularyzator historii regionalnej. Jest autorem artykułów poświęconych $\mathrm{m}$. in. tematyce wojskowej i ochronie infrastruktury krytycznej. Obecnie swoje badania skupia na 63. Toruńskim Pułku Piechoty. Strona: https://www.facebook.com/63PulkPiechoty/
} 
ły, która jako pierwsza poruszała zagadnienia związane z infrastrukturą i topografią poligonu artyleryjskiego ${ }^{1}$. Niestety praca ta aktualnie jest uważana za zagubioną. Kolejną publikacją jest monografia Stanisława Wasilewskiego, który na kilkudziesięciu stronach opisał najważniejsze epizody z czterystu lat istnienia poligonu ${ }^{2}$. Kompleksowym rozwinięciem tematów przyrodniczych poligonu są: praca zbiorowa pod redakcją Jerzego Holca ${ }^{3}$ oraz opracowanie przygotowane przez firmę Fundeko na zlecenie Rejonowego Zarządu Infrastruktury w Bydgoszczy ${ }^{4}$. Wymienione opracowania poruszają kwestie związane $\mathrm{z}$ ochroną środowiska poligonowego oraz $\mathrm{w}$ przystępnej formie podają takie informacje, jak chociażby rzetelny spis wszystkich zagrożonych, chronionych oraz ginących gatunków roślin i zwierząt.

\section{Rys historyczny funkcjonowania poligonu w latach 1607-2017}

Stacjonujące w Toruniu wojska, które z czasem przeobrażały się w regularne i zawodowe szeregi żołnierzy, potrzebowały odpowiedniego miejsca do wspólnych manewrów. Stąd też dookoła miasta, zarówno na prawym, jak i na lewym brzegu Wisły były rozlokowane place ćwiczeń dla wojska, gdzie doskonalono zgranie żołnierzy podczas musztry. Ponadto szybki rozwój artylerii doprowadził do konieczności poszukiwania nowych, oddalonych od miasta miejsc, które mogłyby służyć do ćwiczeń różnego rodzaju wojsk przy wsparciu ciężkich dział.

Rozkwit toruńskiego ośrodka poligonowego nastąpił w XIX w. Jednak przeszło czterystuletnia historia poligonu artyleryjskiego w Toruniu rozpoczęła się w 1607 r. Większość uczonych wybiera tę datę, ponieważ w tym roku odbyło się tu pierwsze zorganizowane strzelanie. Strzelania artyleryjskie organizowano $\mathrm{w}$ miarę regularnie i miały one określony porządek. Działa ustawiano na prawym brzegu Wisły w pobliżu

\footnotetext{
${ }^{1}$ R. Niedbała, Historia poligonu toruńskiego, Toruń 1994.

${ }^{2}$ S. Wasilewski, Zarys historii toruńskiego poligonu artyleryjskiego, Torun 2004.

${ }^{3}$ Przyroda toruńskiego poligonu, red. J. Holc, Torun 2018.

${ }^{4}$ Plan ochrony środowiska poligonu wojskowego Centrum Szkolenia Artylerii i Uzbrojenia w Toruniu, 2012.
} 
ruin zamku krzyżackiego i kierowano je w stronę Kępy Bazarowej, gdzie znajdowała się tarcza ${ }^{5}$. W siedemnastym wieku ćwiczenia odbywały się co kilka lat, a przyjeżdżali na nie puszkarze z różnych stron, przeważnie $z$ terenów Prus Królewskich i Korony. Prawdopodobnie $\mathrm{w}$ ćwiczeniach uczestniczyli także kanonierzy z ziemi litewskiej. W 1625 r. wybrano nowe miejsce (na terenie dzisiejszego poligonu) do prowadzenia działań artylerii. Było nim podnóże Góry Kątowej, która znajduje się na południe od dzisiejszych Stawek, między górami Artyleryjską i Graniczną. Artylerzyści cały czas szukali nowych możliwości i terenów do prowadzenia ćwiczeń. Stąd też podczas potopu szwedzkiego w 1657 r. szwedzki garnizon stacjonujący w Toruniu udał się na miejsce obecnego przystanku PKP Toruń Kluczyki (niegdyś opustoszałe) w celu oddania próbnych salw armatnich. Przy Górze Kątowej ponownie odbyły się manewry, tym razem zarządzone przez wojsko polskie, na czele z hetmanem polnym koronnym Jerzym Sebastianem Lubomirskim. Wiosną 1659 r. oddziały Lubomirskiego spotkały się z wracającymi z Danii wojskami regimentarza Stefana Czarnieckiego. Wspólne ćwiczenia miały na celu zgranie ze sobą obydwu armii, które szły na odsiecz Rzeczypospolitej ${ }^{6}$. Począwszy od pierwszego rozbioru Polski w 1772 r. aż do 1812 r. toruński poligon artyleryjski nie odgrywał znacznej roli w życiu militarnym miasta. $\mathrm{Na}$ początku dziewiętnastego wieku na toruńskim placu ćwiczeń widać było ruchy wojsk francuskich, $\mathrm{z}$ największym ich nagromadzeniem $\mathrm{w}$ 1812 r. Jako wspomnienie i chęć upamiętnienia tamtych wydarzeń okoliczni mieszkańcy nazwali przydrożną kapliczkę - napoleońską. Została ona wybudowana w 1765 r. i nadano jej wezwanie Matki Boskiej Częstochowskiej ze względu na barokowy ołtarz z obrazem, na którym znajdował się wizerunek patronki. Kapliczka przetrwała działania wojenne oraz ćwiczenia poligonowe wojsk i dopiero w 1974 r.

\footnotetext{
${ }^{5}$ T. Janowski, Historja Bractwa Strzeleckiego w Toruniu, [w:] Ksiegga Pamiatkowa Bractwa Strzeleckiego w Toruniu wydana z okazji 575-letniej rocznicy istnienia, Toruń 1927, s. 6.

${ }^{6} \mathrm{Na}$ pamiątkę tych wydarzeń dwa wzgórza znajdujące się na terenie poligonu otrzymały nazwy: Góra Czarnieckiego i Góra Hetmańska.
} 
została przeniesiona jako zabytek do Wielkopolskiego Parku Etnograficznego w Dziekanowicach ${ }^{7}$.

Druga połowa dziewiętnastego wieku przyniosła istotną zmianę w funkcjonowaniu i modernizowaniu poligonu. Strzelnica mieszcząca się na Kępie Bazarowej z czasem okazała się przestarzała, a rozpoczęcie budowy mostu drogowo-kolejowego przez Wisłę w latach 1870 1873 doprowadziło do ostatecznego przeniesienia ćwiczeń wojskowych na lewy brzeg rzeki. Plany dotyczące powstawania i rozbudowy dziewiętnastowiecznej twierdzy Toruń ukazują również rozbudowę infrastruktury militarnej na piaszczystych terenach między Podgórzem a Stawkami. Na przykład na planie z 1886 r. zostały zaznaczone nowe strzelnice na przedpolu Fortu VI Winrych von Kniprode ${ }^{8}$, a wytyczone we wcześniejszych latach miejsca strzelań opisano jako stare. Na późniejszych mapach z końca dziewiętnastego wieku obszar na południe od Podgórza i Stawek jest już nazywany Fußartillerie-Schießplatz, czyli strzelnica artylerii pieszej.

Po rozbudowie fortyfikacji i stworzeniu wojskowych ośrodków szkoleniowych na lewym brzegu Wisły nastąpiło uroczyste poświęcenie toruńskiego poligonu artyleryjskiego ${ }^{9}$. W tym czasie również $\mathrm{w}$ lokalnej prasie pojawiło się wiele wzmianek dotyczących prowadzenia strzelania ostrymi nabojami na poligonie artylerii. Warto zaznaczyć, że plac ćwiczeń znajdował się tuż przy granicy z Rosją, a artylerzyści mylący kierunki niekiedy ostrzeliwali rosyjskie tereny. Zaistniałe sytuacje najczęściej łagodzono wzajemną korespondencją dyplomatyczną.

Przy górach o nazwie Sypka, Jodłowa i Batorego Prusacy wznieśli również polowe umocnienia oddalone od fortyfikacji, ale dostosowane do obrony twierdzy. Poligon został wyposażony w cztery potężne wieże obserwacyjne, które rozmieszczono na granicy, oraz dwadzieścia cztery mniejsze stanowiska do obserwacji, skonstruowane z blachy falistej, mieszące się na całym terenie poligonu. Wszystkie elementy tego systemu zostały połączone siecią telefoniczną, co usprawniało mobil-

${ }^{7}$ S. Wasilewski, A. Hermann, Toruński poligon artyleryjski, Kujawy i Pomorze 2007, nr 1 , s. 13

${ }^{8}$ Obecnie fort nosi nazwę: Fort XIII Karola Kniaziewicza.

${ }^{9}$ S. Wasilewski, op. cit., s. 12 
ność działań na poligonie. Początkowo wszelki transport po piaszczystych terenach do ćwiczących wojsk odbywał się za pomocą koni pociągowych i furmanek. Jednak jego nieefektywność spowodowała konieczność zwiezienia i zmontowania na terenie poligonu trzydziestu kilometrów torów (dziennie robotnicy mogli ułożyć do trzech kilometrów żelaznej drogi), tworząc jednocześnie pierwsze zaczątki poligonowej kolejki wąskotorowej o rozstawie szyn rzędu sześćdziesięciu centymetrów. Powstała w 1884 r. kolejka co prawda nie była profesjonalna ze względu chociażby na jej sposób wykonania, ale z pewnością okazała się praktyczna. Żołnierze mocowali szyny na drewnianych podkładach, a następnie bez zwracania uwagi na formę terenu i zachowanie poziomu układali je w jednym ciągu. Następnie dwumetrowe przęsła skręcano ze sobą i tak powstawało torowisko, które zdecydowanie przyspieszyło transport $\mathrm{w}$ głąb poligonu i całkowicie wyeliminowało problem furmanek grzęznących na piaszczystych odcinkach drogi ${ }^{10} . \mathrm{W}$ 1901 r., a następnie w 1903 i 1906, unowocześniono kolejkę, a właściwie zaczęto wznosić ją na nowo. Cała inwestycja łącznie obejmowała 32,2 kilometry torowiska. Taki zabieg był konieczny ze względu na zmodernizowanie siły pociągowej. Dawne konne zaprzęgi zastąpił parowóz, który wymagał odpowiedniego wypoziomowania torów. Jego wysoki środek ciężkości i mały rozstaw szyn prowadziły do częstych wywrotek. Taki wypadek wydarzył się kilka miesięcy po otwarciu udoskonalonej wąskotorówki. Lokalna prasa donosiła, że na wysokości miejscowości Dziwaki w wyniku wykolejenia się kolejki fortyfikacyjnej zginął jeden żołnierz, a czterech zostało ciężko rannych ${ }^{11}$. Nowa kolej z czternastoma parowozami zapewniała sprawny transport między magazynami czy też trzytysięcznym miasteczkiem poligonowym. Służyła Prusakom do czasu I wojny światowej, kiedy to została zdemontowana i przeniesiona w głąb toruńskiej twierdzy. Do dnia dzisiejszego na terenie poligonu można odnaleźć charakterystyczne nasypy, które są pozostałościami po wąskotorowej kolei fortyfikacyjnej, bądź współczesne drogi, na których kiedyś funkcjonowała wąskotorówka.

${ }^{10}$ J. Pokrzywnicki, Toruński Poligon Artyleryjski, cz. I, http://www.stawki.org/node /89, (28.04.2018 r.).

${ }^{11}$ Wypadek kolei fortyfikacyjnej, Gazeta Toruńska, 1902, nr 110, s. 2. 
Po odzyskaniu przez Polskę niepodległości i wkroczeniu w 1920 r. Dywizji Pomorskiej na tereny Podgórza nastąpiło przejęcie całej administracji poligonu przez późniejsze DOK nr VIII. Dowództwo, wykorzystując zabudowania koszarowe i magazyny pozostawione przez Niemców, powołało do życia w 1921 r. Szkołę Strzelań Artylerii, przeobrażoną później w Centrum Wyszkolenia Artylerii. Od 1924 r. toruński poligon artyleryjski otrzymał miano Centralnego Poligonu Artylerii, stając się nowoczesnym i dobrze wyposażonym placem ćwiczeń. W tym okresie również dla zwiększenia bezpieczeństwa ludności cywilnej zamontowano sieć znaków ostrzegawczych: na maszcie znajdowały się specjalne kosze, które były podnoszone do góry, gdy na poligonie odbywało się strzelanie ostrymi nabojami. Z pewnością można stwierdzić, że w okresie dwudziestolecia międzywojennego Toruń wraz ze swoim poligonem stał się ważnym miejscem szkolenia przyszłych kadr wojsk artylerii w II Rzeczypospolitej.

W czasie okupacji hitlerowskiej toruński poligon stał się miejscem szkolenia wojsk przed wyruszeniem na front, a także ćwiczeń z bronią przeciwpancerną. Trzymane przez Niemców w tajemnicy manewry do dziś pozostawiły po sobie ślady. Najczęściej spotykane są fragmenty odłamków amunicji, łusek, płyt przeciwpancernych bądź większych świadków tamtych wydarzeń, jakimi są schrony o pokaźnej grubości ścian i wielu stalowych zbrojeniach. Okupanci również wznieśli na obszarze poligonu kilka prostych domów/ścian, które miały przygotować szkolone na placu ćwiczeń wojska do walk w mieście.

W czasach Polskiej Rzeczypospolitej Ludowej toruński poligon artyleryjski z dniem 5 kwietnia 1945 r. został przeobrażony w Centralny Poligon Artyleryjski nr 1. Do Torunia przybyły radziecko-polskie kadry oficerskie oraz kilkudziesięciu żołnierzy służby zasadniczej, którzy byli odpowiedzialni za rozpoznanie obszaru poligonu, rozminowanie i przygotowanie jego infrastruktury dla nowej administracji. Przejęty poniemiecki teren został szybko oczyszczony i już prawie po roku rozpoczęto tu pierwsze strzelania artyleryjskie prowadzone przez 59. Zaporowy Pułk Artylerii oraz wybudowano warsztaty, które zajmowały się tworzeniem celów dla artylerii ${ }^{12}$. Do końca lat czterdzie-

${ }^{12}$ S. Wasilewski, op. cit., s. 20. 
stych ubiegłego wieku, poza przyłączeniem następnych wiosek do obszaru poligonu, nie działo się nic. Był to czas prowadzenia skromnych ćwiczeń na zdobycznym sprzęcie i nieznacznej rozbudowy betonowych stanowisk obserwacyjnych na górach Długa, Sypka, Jodłowa, Artyleryjska i Batory oraz utworzenia dwóch kilometrów Drogi Wódeckiej i wzniesienia Wieży Orlej ${ }^{13}$. Dopiero pod koniec lat pięćdziesiątych i na początku lat sześćdziesiątych XX w. nastąpił znaczący rozwój ośrodka poligonowego. W tym czasie żelbetonowe schrony pobudowano na kilku następnych górach. Rozbudowano także zaplecze stacji metrologicznej. Z roku na rok podczas wizytacji komenda poligonu otrzymywała oceny bardzo dobre, a infrastruktura placu ćwiczeń i obiektów koszarowych cały czas się rozwijała ${ }^{14}$. Prężny rozwój artylerii doprowadził do częstych ćwiczeń i szkoleń w armii. W 1964 r., kiedy prowadzono ćwiczenia z nowoczesnymi sprzętem, odbyło się łącznie około 23400 strzelań ze stanowisk zakrytych i prowadzenia ognia na wprost. W 1971 r. na toruńskim poligonie artyleryjskim wystrzelono po raz pierwszy rakietę taktyczną. W latach siedemdziesiątych odbywały się tu intensywne ćwiczenia w strzelaniu. Również w tych latach zgromadzono w sumie kilkadziesiąt tysięcy ton ładunków. W latach osiemdziesiątych ćwiczenia były również prowadzone, jednak z mniejszym i oszczędnym wykorzystaniem siły artylerii. Wyjątkiem może być rok 1986, kiedy na toruńskim placu ćwiczeń sztab Wojsk Rakietowych i Artylerii Ministerstwa Obrony Narodowej zorganizował ćwiczenia taktyczne połączone $\mathrm{z}$ prowadzeniem ostrzału przez rakiety kasetowe ${ }^{15}$. W latach dziewięćdziesiątych ubiegłego wieku postanowiono zlikwidować Ośrodek Szkolenia Poligonowego Artylerii w Toruniu, a pozostały plac ćwiczeń przekazano WSO im. Józefa Bema. Następne reformy szkolnictwa wojskowego przyniosły likwidację toruńskiej WSO, a poligon artyleryjski przypisano do powstałego Centrum Szkolenia Artylerii i Uzbrojenia, gdzie pozostaje do dziś.

Współcześnie poligon artyleryjski w Toruniu jest jednym z największych poligonów Europy. Zachowuje przez cały czas swój cha-

\footnotetext{
${ }^{13}$ Kronika Jednostki Wojskowej, 2603, t. I, lata 1945-1974, s. 3.

${ }^{14}$ Ibid., s. 3-6.

${ }^{15}$ S. Wasilewski, op. cit., s. 21.
} 
rakter szkoleniowy, a na jego ziemiach ćwiczą jednostki Garnizonu Toruń oraz inne formacje z całej Polski. Manewry na placu ćwiczeń i prowadzenie strzelań odbywają się cyklicznie. Jednak ostatnimi ćwiczeniami na wielką skalę była Anakonda 16 zorganizowana przy współpracy wojsk sojuszniczych NATO w czerwcu $2016 \mathrm{r}$.

\section{Poligon i mieszkańcy Torunia w świetle informacji „Gazety Toruńskiej” (1867-1921) i „Słowa Pomorskiego” (1921-1939)}

„Gazeta Toruńska” przez cały czas swojego istnienia publikowała informacje dotyczące rozwijającego się placu ćwiczeń dla artylerzystów ulokowanego na Podgórzu. Najwięcej wzmianek pojawiło się jednak pod koniec dziewiętnastego wieku i na początku wieku dwudziestego. Prawdopodobnie jest to związane z rozbudową, a właściwie już zakończeniem prac budowlanych przy fortecznej toruńskiej twierdzy pierścieniowej. Ukończone prace doprowadziły do możliwości skoszarowania wojsk w fortach, a same warownie stały się bazą wypadową w kierunku poligonu, stąd też nasiliły się ćwiczenia przeprowadzane przez Prusaków.

W lokalnej gazecie najczęściej pojawiały się informacje dotyczące strzelań artyleryjskich na poligonie. Niemal każdy taki komunikat opatrzony jest nagłówkiem „Strzelanie ostremi nabojami”. Dowiadujemy się, że ćwiczenia na poligonie odbywały się często. Strzelano przez kilka bądź kilkanaście dni w miesiącu, a niekiedy przez cały miesiąc. W przeddzień wybuchu I wojny światowej zaplanowano nawet ciąg strzelań rozłożony na cały miesiąc, ale wojna zmusiła do odsyłania ćwiczących wojsk do swoich garnizonów ${ }^{16}$. Wiadomo również, $w$ jakich godzinach były prowadzone ćwiczenia. Najczęściej rozpoczynały się one między godziną szóstą a ósmą rano, zawsze o pełnych godzinach. Koniec przeważnie był planowany na godzinę trzecią po południu ${ }^{17}$. Odbywające się cyklicznie na poligonie manewry były prowadzone również $\mathrm{w}$ nocy ${ }^{18}$.

\footnotetext{
${ }^{16}$ Strzelanie ostremi nabojami, Gazeta Toruńska, 1914, nr 168, s. 3.

${ }^{17}$ Godziny strzelań, Gazeta Toruńska, 1911, nr 70, s. 2.

${ }^{18}$ Nocne ćwiczenia, Gazeta Toruńska, 1908, nr 227, s. 2.
} 
Często przy ogłoszeniach informujących o ostrym strzelaniu na poligonie ostrzegano mieszkańców Torunia o grożącym im niebezpieczeństwie. Pojawiające się komunikaty powiadamiały o bezwzględnym zakazie wchodzenia na plac ćwiczeń podczas strzelań, zamkniętych drogach i wartownikach oraz patrolach wojskowych pilnujących granic poligonu. Ponadto torunianom nie były też obce znaki ostrzegawcze w formie zawieszonych koszy na masztach, które były umieszczone na skarpach poligonowych fortów. Sygnalizatory były tak ulokowane, że można je było dostrzec już z daleka ${ }^{19}$.

Pomimo wszelkich ostrzeżeń i częstokroć pojawiających się komunikatów, toruńska i okoliczna ludność była ciekawa tajemnic poligonu i często wbrew zakazom odwiedzała plac ćwiczeń. Z „Gazety Toruńskiej” znanych jest wiele przypadków skrajnej nieodpowiedzialności i narażania zdrowia. Najczęstszymi pobudkami do odwiedzania poligonu artyleryjskiego była zwykła ciekawość. Z gazety dowiadujemy się o pewnej kobiecie, która mimo wszelkich zakazów i ostrzeżeń weszła na teren strzelań przy forcie na Rudaku i została raniona pociskiem armatnim. Informację tę po pewnym czasie „Gazeta” odwołała, jednak takie sytuacje były codziennością na toruńskim poligonie artyleryjskim $^{20}$. Ofiarami tajemniczych wydmowych terenów były najczęściej dzieci. Znane są dramatyczne przypadki, kiedy małoletni majstrowali przy wszelkich poligonowych znaleziskach. Taka sytuacja wydarzyła się w 1902 r. Piątka dzieci pochodząca z Dębińca zbierała niewypały. Nagle jeden z granatów wybuchł i ranił całą grupę. Trzymający go piętnastoletni Józef Wiśniewski na skutek doznanych obrażeń zmarł podczas drogi do rodzinnej wsi. Reszta, odnosząc znaczne urazy, została odtransportowana do rodzinnych domów, a jednego $\mathrm{z}$ chłopców przewieziono do inowrocławskiego domu chorych ${ }^{21}$. Szesnastoletni syn robotnika Maćkiewicza przyniósł z poligonu do domu nabój i starał się go rozebrać. Wybuch, który nastąpił, poranił mu dłonie i poparzył twarz 22 .

${ }^{19}$ Znaki ostrzegawcze, Gazeta Toruńska, 1897, nr 6, s. 2.

${ }^{20}$ Kobieta na poligonie, Gazeta Toruńska, 1892, nr 128, s. 3.

${ }^{21}$ Dzieci z Dębińca, Gazeta Toruńska, 1902, nr 133, s. 2.

${ }^{22}$ Ranny syn robotnika, Gazeta Toruńska, 1911, nr 136, s. 2. 
Okazuje się, że nie tylko okoliczna ludność była zaciekawiona niewypałami bądź niewybuchami, ale również sami żołnierze pełniący służbę na placu ćwiczeń. W 1904 r. w ciągu kilku miesięcy wydarzyło się kilkanaście wypadków z ich udziałem. Pewnego razu jeden z żołnierzy zabrał ze sobą do koszar nabój, który zdetonował się wśród jego kolegów. Pocisk ranił będących w izbie szeregowych, jednego nawet pozbawiając wzroku ${ }^{23}$. W lipcu tego samego roku można odnaleźć $\mathrm{w}$ gazecie informację o żołnierzach, którzy bawili się kartaczem. Nastąpił wybuch, a odłamki okaleczyły kilku z nich ${ }^{24}$. Nie zawsze jednak takie sytuacje kończyły się tylko powierzchownymi obrażeniami. W $1908 \mathrm{r}$. szeregowy z 15. pułku artylerii zabrał ze sobą do koszarowego baraku niewystrzelony pocisk. Podczas rozbierania znaleziska nastąpiła eksplozja, która rozerwała żołnierza na strzępy i przy okazji raniła jego współtowarzyszy ${ }^{25}$.

Nie tylko ciekawość, ale także chęć wzbogacenia się kierowała tutejszą ludność na tereny poligonu artyleryjskiego, nawet wtedy, kiedy trwały ćwiczenia. Wiele fragmentów stali, porozrzucanych odłamków stało się łatwym łupem i szybko przynosiło zysk. Niekiedy udawało się je sprzedać, a czasami były przyczyną śmierci zbieraczy. Już pod koniec dziewiętnastego wieku postanowiono wybudować wielki piec do przetapiania odłamków. Projektem zajęła się firma Drewitz, która wzniosła piec w ciągu kilku dni tuż przy warsztacie Ganotta, zajmującego się budową statków. Pociągnięto tam nawet tory kolejowe, aby ułatwić bezpośredni transport odłamków do pieca ${ }^{26} . \mathrm{Z}$ biegiem lat wkroczyła na rynek poligonowy również firma C. B. Dietrich, która początkowo miała postawić piec razem z Drewitzem. Koncern cyklicznie wykupywał odłamki od komendantury placu ćwiczeń, aż w końcu stał się właścicielem wszystkich poligonowych odłamków. Można powiedzieć, że firma C. B. Dietricha była jedną z pierwszych robiących porządki na polu roboczym poligonu. W „Gazecie Toruńskiej” z 1902 r. pojawiła się informacja, że wszelkie odłamki znajdujące się na poligo-

${ }^{23}$ Żotnierze 5 pułku artylerii, Gazeta Toruńska, 1904, nr 115, s. 2.

${ }^{24}$ Żotnierze 6 pułku artylerii, Gazeta Toruńska, 1904, nr 165, s. 2.

${ }^{25}$ Żotnierz 15 pułku artylerii, Gazeta Toruńska, 1908, nr 108, s. 5.

${ }^{26}$ Piec Drewitz, Gazeta Toruńska, 1896, nr 186, s. 2. 
nie są własnością tej fabryki, a za ich zbieranie są odpowiedzialne osoby, które zostały wyznaczone przez firmę ${ }^{27}$. Z pewnością ograniczyło to ilość artyleryjskich śmieci znajdujących się na poligonie, jednak amatorów zbierania metalowych niewypałów cały czas nie brakowało.

Garnizon Toruń co jakiś czas organizował wstęp dla ludności cywilnej na plac ćwiczeń, w celu oglądania strzelań artyleryjskich ${ }^{28}$, aby ograniczyć nielegalne przebywanie mieszkańców Torunia na poligonie.

Regularne ćwiczenia artyleryjskie na toruńskim poligonie często dawały się we znaki mieszkańcom miasta. Nocne manewry budziły mieszkańców, zakłócając im spokój i przerywając $\operatorname{sen}^{29}$. Tego typu skargi można znaleźć w „Gazecie Toruńskiej”. Artyleria nie tylko zakłócała sen, ale również czyniła wiele szkód. Niekoniecznie bombardowaniem obiektów cywilnych, chociaż takie pomyłki się zdarzały, ale samym drganiem spowodowanym wystrzałem armat. Wielu mieszkańców Torunia skarżyło się na popękane ściany i sufity, pojawiające się odpryski i spadające ozdoby. Gazownia mieszcząca się na Podgórzu również ucierpiała, kiedy to podczas strzelań wypadło przeszło trzydzieści szyb ${ }^{30}$. Już od końca dziewiętnastego wieku toruńska landratura zamieszczała ogłoszenia $\mathrm{w}$ gazecie dotyczące zbadania szkód i wypłaty odszkodowań za poniesione straty wywołane wstrząsami ziemi od wystrzałów armatnich z toruńskiego poligonu artyleryjskiego ${ }^{31}$.

Po odzyskaniu przez Polskę niepodległości i ówczesnych zawirowaniach politycznych powstała gazeta o nazwie "Słowo Pomorskie”. W pewnym sensie zastąpiła „Gazetę Toruńską" jako najpoważniejszy dziennik w mieście. Garnizon Toruń rozwijał się prężnie, stąd też żołnierze przebywający na ulicach miasta byli zjawiskiem normalnym. Również przejęty z rąk Niemców poligon artyleryjski był stopniowo odnawiany, a jego ziemie zaczęły służyć polskim artylerzystom. Podobnie jak to było w poprzednim wieku gazeta nagminnie komunikowała o odbywających się ćwiczeniach artylerii i o grożącym niebez-

${ }^{27}$ Odłamki własności firmy C. B. Dietrich, Gazeta Toruńska, 1902, nr 59, s. 2.

${ }^{28}$ Oglądanie strzelań artyleryjskich, Gazeta Toruńska, 1912, nr 36, s. 2.

${ }^{29}$ Nerwowi mieszkańcy Torunia, Gazeta Toruńska, 1905, nr 175, s. 2.

${ }^{30}$ Pęknięte szyby w gazowni, Gazeta Toruńska, 1911, nr 195, s. 1.

${ }^{31}$ Landratura w sprawie szkód wywołanych ćwiczeniami artylerii, Gazeta Torunska, 1896, nr 156, s. 3. 
pieczeństwie. Strzelania trwały nawet całe miesiące ${ }^{32}$. Miejscowa ludność jednak nie stosowała się do ogłaszanych ostrzeżeń i mimo wszelkich zakazów wchodziła na teren poligonu. Nowością w lokalnych gazetach były komunikaty, które szczegółowo podawały wszelkie ostrzeżenia związane z placem ćwiczeń. W jednym z takich ogłoszeń można dokładnie wyczytać, jak poligon był zabezpieczany przed niechcianymi gośćmi oraz jak wojsko ostrzegało mieszkańców przed niebezpieczeństwem $^{33}$. W 1935 r. w czasopiśmie „Tygodnik Toruński” Zarząd Miejski w Toruniu opublikował zawierający 68 punktów wyciąg z „Regulaminu Poligonu Obozu Ćwiczebnego Centrum Wyszkolenia Artylerji w Toruniu" 34 .

Stopniowo liczba ranionych dorosłych osób zmniejszała się. Możliwe, że zbieranie metali kolorowych nie było już tak opłacalne i nie warto było ryzykować życia dla kilku złotówek. Natomiast liczba ofiar wśród dzieci utrzymywała się mniej więcej na tym samym poziomie. W „Słowie Pomorskim”, podobnie jak w „Gazecie Toruńskiej”, były jednak informacje o dramatycznych przypadkach związanych z małoletnimi $^{35}$. Z pierwszych stron gazety możemy też dowiedzieć się o tragicznej śmierci dwóch młodzieńców. Trzej koledzy wybrali się na niedzielny spacer w kierunku poligonu na Podgórzu. Powód spaceru nie był znany, ale prawdopodobnie jego celem było poszukiwanie odłamków. Dziewiętnastoletni Jan Czołguszewski i piętnastoletni Willi Fenski ponieśli śmierć $\mathrm{w}$ wyniku manipulowania przy znalezionym granacie. Trzeci z kolegów, siedemnastoletni Józef Sawicki, odniósł najmniejsze obrażenia w postaci oparzeń i małych okaleczeń ${ }^{36}$.

Wśród szeregowych szkolących się na poligonie zdarzało się bardzo mało przypadków bezmyślności zawodowych żołnierzy w porównaniu z tymi opisanymi w „Gazecie Toruńskiej”. W „Słowie Pomorskim” znajdujemy niewiele informacji na ten temat. Najczęstszymi przykładami są po prostu wypadki podczas pełnionej służby. Często z gazety

\footnotetext{
${ }^{32}$ Ostre strzelanie na poligonie, Słowo Pomorskie, 1928, nr 81, s. 9.

${ }^{33}$ Jeśli ci życie mile czyli przepisy poligonu, Słowo Pomorskie, 1931, nr 162, s. 8.

${ }^{34}$ Pełną treść wyciągu regulaminu zob. Tygodnik Toruński, 1935, nr 44, s. 3-7.

${ }^{35}$ Wypadek na poligonie, Słowo Pomorskie, 1926, nr 182, s. 8.

${ }^{36}$ Tragiczna śmierć dwóch młodzieńców, Słowo Pomorskie, 1931, nr 177, s. 1.
} 
można dowiedzieć się o żołnierzach zranionych podczas manewrów na poligonie $^{37}$ bądź śmierci na służbie, tak jak w przypadku trzech żołnierzy 1. baterii Grupy Szkolnej Artylerii Toruń-Podgórz ${ }^{38}$.

W dwudziestoleciu międzywojennym Szkoła Strzelania Artylerii w Toruniu ogłosiła konkurs na uruchomienie komunikacji konnej bądź automobilowej między poligonem a Rynkiem Nowomiejskim ${ }^{39}$. Dzień wcześniej w „Słowie Pomorskim” pojawiło się ogłoszenie taryfy dorożkarskiej; za transport jednej osoby ze śródmieścia do Podgórza lub na poligon cena wynosiła $2,60 \mathrm{zl}$, od dwóch osób płacono $2,80 \mathrm{zl}$, za trzy osoby 3 zl, a za cztery $3,50 \mathrm{zt}^{40}$.

Niepraktykowaną we wcześniejszych latach legalną formą przebywania na toruńskim poligonie stały się regularne wycieczki organizowane przez różne towarzystwa w porozumieniu z komendą poligonu w Toruniu. W 1922 r. do Grodu Kopernika przybyli z Rembertowa weterani wyższego kursu dowodzenia piechoty i między innymi zwiedzali poligon ${ }^{41}$. Plac ćwiczeń był dostępny nie tylko dla byłych wojskowych, ale również dla osób cywilnych. Częste wycieczki na toruński poligon organizowały Towarzystwo Miłośników Przyrody i Koło Miłośników Przyrody ${ }^{42}$; podziwiano tam florę stepową i słuchano wykładów profesora Kwiatkowskiego na ten temat ${ }^{43}$.

W „Słowie Pomorskim” po raz pierwszy został opublikowany opis infrastruktury poligonu i panujących tam warunków przyrodniczych. Wcześniej nigdzie $w$ gazetach nie można spotkać tak obszernych informacji na temat poligonu. Artykuł zawiera zwięzły opis strzelnic, ukształtowania terenu i roślinności oraz fortów znajdujących się w jego granicach. Autor przedstawia przykładowe manewry, które mogłyby się tu odbyć, ukazując jednocześnie codzienne życie żołnierza podczas pełnienia służby na toruńskim poligonie ${ }^{44}$.

${ }^{37}$ Zranienie podczas manewrów, Słowo Pomorskie, 1925, nr 193, s. 10.

${ }^{38}$ Nieszczéśliwy wypadek podczas petnienia stużby, Słowo Pomorskie, 1921, nr 97, s. 6.

${ }^{39}$ Konkurs na komunikacje miejska na trasie Rynek Nowomiejski - Poligon, Słowo Pomorskie, 1924, nr 88, s. 20.

${ }^{40}$ Taryfa dorożkarska, Słowo Pomorskie, 1924, nr 87, s. 5.

${ }^{41}$ Wycieczka weteranów z Rembertowa, Słowo Pomorskie, 1922, nr 144, s. 6.

${ }^{42}$ Wycieczka Koła Miłośników Przyrody, Słowo Pomorskie, 1931, nr 133, s. 8.

${ }^{43}$ Wycieczka Towarzystwa Miłośników Przyrody, Słowo Pomorskie, 1931, nr 82, s. 8

${ }^{44}$ Na poligonie toruńskim, Słowo Pomorskie, 1926, nr 198, s. 5. 
Obecność poligonu wiąże ze sobą wiele różnych historii, wspominanych na stronach „Słowa Pomorskiego”. Jedną z nich może być ukazanie dobrych relacji pomiędzy mieszkańcami Podgórza a dowództwem poligonu artyleryjskiego, kiedy kadra oficjalnie dziękowała organizacjom i mieszkańcom, wymieniając ich z imienia i nazwiska, za zorganizowanie „święconego"w ich oddziale ${ }^{45}$.

\section{Bibliografia}

\section{Źródła}

„Gazeta Toruńska”, 1892, nr 128, s. 3.

„Gazeta Toruńska”, 1896, nr 156, s. 3; nr 186, s. 2.

"Gazeta Toruńska”, 1897, nr 6, s. 2.

„Gazeta Toruńska”, 1902, nr 59, s. 2; nr 110, s. 2; nr 133, s. 2.

„Gazeta Toruńska”, 1904, nr 115, s. 2.

„Gazeta Toruńska”, 1905, nr 175, s. 2.

„Gazeta Toruńska”, 1908, nr 108, s. 5; nr 227, s. 2.

„Gazeta Toruńska”, 1911, nr 70, s. 2; nr 136, s. 2; nr 195, s. 1.

„Gazeta Toruńska”, 1912, nr 36, s. 2.

„Gazeta Toruńska”, 1914, nr 168, s. 3.

Kronika Jednostki Wojskowej, 2603, t. I, lata 1945-1974, w zbiorach CSAiU.

Regulamin Poligonu Obozu Ćwiczebnego Centrum Wyszkolenia Artylerii, kopia w zbiorach CSAiU.

„Słowo Pomorskie”, 1921, nr 72, s. 4; nr 97, s. 6.

„Słowo Pomorskie”, 1922, nr 144, s. 6.

„Słowo Pomorskie”, 1924, nr 87, s. 5; nr 88, s. 20.

„Słowo Pomorskie”, 1925, nr 193, s. 10.

„Słowo Pomorskie”, 1926, nr 182, s. 8; nr 198, s. 5.

„Słowo Pomorskie”, 1928, nr 81, s. 9.

„Słowo Pomorskie”, 1931, nr 82, s. 8; nr 133, s. 8; nr 162, s. 8; nr 177, s. 1.

„Tygodnik Toruński”, 1935, nr 44, s. 3-7.

Opracowania

Janowski T., Historja Bractwa Strzeleckiego w Toruniu, [w:] Księga Pamiątkowa Bractwa Strzeleckiego w Toruniu wydana z okazji 575-letniej rocznicy istnienia, Toruń 1927.

\footnotetext{
${ }^{45}$ Organizacja przez mieszkańców Podgórza święconego w oddziale Dowództwa Poligonu Artylerji, Słowo Pomorskie, 1921, nr 72, s. 4.
} 
Niedbała R., Historia poligonu toruńskiego, Toruń 1994.

Plan ochrony środowiska poligonu wojskowego Centrum Szkolenia Artylerii $i$ Uzbrojenia $w$ Toruniu, opracowanie wykonane przez firmę Fundeko na zamówienie Rejonowego Zarządu Infrastruktury w Bydgoszczy, 2012.

Przyroda toruńskiego poligonu, red. J. Holc, Toruń 2018.

Wasilewski S., Zarys historii toruńskiego poligonu artyleryjskiego, Toruń 2004.

Wasilewski S., Hermann A., Toruński poligon artyleryjski, Kujawy i Pomorze 2007, nr 1, s. 11-17.

Publikacje internetowe

Pokrzywnicki J., Toruński Poligon Artyleryjski, cz. I, http://www.stawki.org/ node/89, (28.04.2018 r.).

Streszczenie: Podjęta przez autora problematyka wpływu poligonu artyleryjskiego na życie Torunia jest pionierskim tematem badawczym. Większość naukowców zajmowało się dziejami poligonu bądź jego fauną i florą. Należy jednak pamiętać, że cała infrastruktura poligonu jest silnie wspierana i rozwijana przez pewien motor napędowy, jakim jest miasto Toruń. Plac ćwiczeń to nie tylko hektary piaszczystych wydm i wrzosowisk, ale również niezliczone historie pojedynczych osób, które odczuły wpływ poligonu na ich życie. Autor, badając temat, postanowił określić ramy czasowe między 1867 a 1939 r. Wybrany przedział został tak zdefiniowany z tego względu, że dla tych lat znajduje się najwięcej wzmianek o toruńskim poligonie, zamieszczonych w lokalnej prasie. Głównymi źródłami niniejszego artykułu są dwie miejscowe gazety. Pierwszą z nich jest „Gazeta Toruńska”, która była wydawana w latach 1867-1921, drugą zaś „Słowo Pomorskie” z lat 1921-1939.

The influence of the artillery firing range on the life of Torun in the years 1867-1939 in the light of the local press

Abstract: The author addresses the problem of the influence of the artillery firing range on the life of Torun, which constitutes a pioneer research work. Most scholars have dealt with the history of the firing range, its fauna and flora. However, it must be remembered that the whole infrastructure of the firing range is strongly supported by the city of Torun. The military training ground constitutes not only hectares of sandy dunes and moors, but also numerous histories of individual people who experienced the influence of the 
firing range on their lives. The author decided to establish the time frameworks between 1867 and 1939 since it was in those years that most records about Torun's firing range appeared in the local press. The main sources of this work are two dailies: „Gazeta Toruńska”, published in the years 18671921, and „Słowo Pomorskie” of 1921-1939.

\section{Der Einfluss des Artillerie-Truppenübungsplatzes auf das Leben in Thorn in den Jahren 1867-1939 im Licht der örtlichen Presse}

Zusammenfassung: Das vom Autor behandelte Thema, der Einfluss des Artillerieübungsplatzes auf das Leben in Thorn, hat in der Forschung Pioniercharakter. Die meisten Wissenschaftler haben sich mit der Geschichte des Truppenübungsplatzes oder mit seiner Flora und Fauna beschäftigt und darüber geschrieben. Es sei jedoch daran erinnert, dass die gesamte Infrastruktur des Truppenübungsplatzes massiv von einem Antriebsmotor gestützt und entwickelt wird, nämlich der Stadt Thorn. Der Übungsplatz, das sind nicht nur hektarweise Sanddünen und Heideland, sondern auch ungezählte Geschichten einzelner Personen, die den Einfluss des Platzes auf ihr Leben an sich selbst erfahren haben. Der Autor hat bei seinen Forschungen zum Thema den zeitlichen Rahmen auf die Jahre zwischen 1867 und 1939 festgelegt. Das geschah deshalb, weil sich in diesen Jahren die meisten Erwähnungen des Thorner Truppenübungsplatzes in der lokalen Presse finden. Die wichtigsten und entscheidenden Quellen der vorliegenden Arbeit sind zwei örtliche Zeitungen. Die erste davon ist die „Gazeta Toruńska“, die in den Jahren 1867 1921 erschien, die zweite ist „Słowo Pomorskie“ aus den Jahren 1921-1939.

Słowa kluczowe: toruński poligon artyleryjski, plac ćwiczeń, mieszkańcy Torunia, „Gazeta Toruńska”, „Słowo Pomorskie”, toruńska prasa

Keywords: Torun's artillery firing range, military training ground, inhabitants of Toruń, „Gazeta Toruńska”, „Słowo Pomorskie”, Toruńs press

Schlüsselwörter: Thorner Artillerie-Truppenübungsplatz, Übungsplatz, Einwohner von Thorn, „Gazeta Toruńska”, „Słowo Pomorskie”, Thorner Presse 